\title{
RHEUMATISM IN SCHOOL CHILDREN.
}

A Report on the L.C.C. Rheumatism Supervisory Clinic, Stoke-Newington.

By CLAUDE ELMAN, M.D., M.R.C.P. (Lond.)

(Assistant Physician, Queen Mary's Hospital for the East End, Stratford; Physician, Margaret Street Hospital for Consumption, W.1; Medical Officer in Charge, Poplar and Stoke-Newington Rheumatism Supervisory Clinics.)

This report on the cases which I have seen and supervised at the StokeNewington Clinic makes no attempt to solve the important problems-the cause and method of spread of the disease.

I had intended to make a study of the subjective symptoms and objective signs in each case and to try and correlate the two findings, but I gave this up as quite impracticable. There was no apparent relationship between the two. On the one hand, cases with severe symptoms were found not only on the occasion of the first examination, but also on all subsequent occasions to have no clinical cardiac disease, while on the other hand, cases with manifest cardiac lesions gave rise both in the past and present to only slight symptoms, or even to none at all. I therefore decided to concentrate on a general analytical study of the patients I had seen and simply attempt to draw some general conclusions.

The cases investigated were quite unselected and were those seen from the time the clinic was first opened in April, I932.

The total number of patients seen up to October I934 were 289 . Of this number 50 are not included in this analysis for various reasons as shown in the following table:-

$\begin{array}{lllll}\text { Left School and refused to return } & \ldots . . & \ldots & \ldots & 23\end{array}$

Refused to return though still of School age $\ldots$... 5

$\begin{array}{lllll}\text { Transferred to other clinics or hospitals } & \ldots & \ldots & \ldots & \text { I2 }\end{array}$

$\begin{array}{lllllllll}\text { Left London } & \ldots & \ldots & \ldots & \ldots & \ldots & \ldots & \ldots & 9\end{array}$

$\begin{array}{llllllllll}\text { Died } & \ldots & \ldots & \ldots & \ldots & \ldots & \ldots & \ldots & \ldots & \text { I }\end{array}$

Total 50

This leaves 239 who were all recommended by the School Medical Officers for one of the following reasons:-

(a) Pains present.

(b) History of pains.

(c) Movements present.

(d) History of movements.'

(e) Abnormal cardiac conditions. 
The cases have been divided into three main groups:-

I. Those in which the heart was regarded as normal at the time of the first examination and in which it remained normal while under observation.

2. Those in which the heart was regarded as abnormal at the first or on a subsequent examination but which was considered to be normal by October I934.

3. Those in which the heart was regarded as abnormal at the first examination or who developed definite cardiac changes while under observation, and remained abnormal in October I934.

Of the first group there were 92 , of the second 43 and of the third there were I04. These figures are very significant as they show a high proportion of cardiac lesions. It is therefore most important to make careful observation of all children who complain of joint or limb pains, a fact which I consider completely justifies the provision of Supervisory Clinics.

\section{Group r.-Cases without Carditis.}

This group comprised 92 children. In 54 there were no physical signs of any disease whatsoever, although 20 of them had previously suffered from some manifestation of rheumatism or other disease liable to induce carditis. Io had suffered from acute rheumatism, 7 from chorea and 3 from scarlatina.

In 38 there were observed signs of disease which provided a possible explanation of the symptoms which had been ascribed to the rheumatic infection. The following table shows the various conditions found:-

$\begin{array}{lccccccr}\text { Orthopædic } \ldots & \ldots & \ldots & \ldots & \ldots & \ldots & \text { II } \\ \begin{array}{l}\text { Septic or/and enlarged tonsils } \\ \text { Nasal obstruction }\end{array} & \ldots & \ldots & \ldots & \ldots & 6 \\ \begin{array}{l}\text { Dental caries } \\ \text { Dental }\end{array} & \ldots & \ldots & \ldots & \ldots & \ldots & \text { I } \\ \text { Albuminuria } & \ldots & \ldots & \ldots & \ldots & \ldots & \ldots & \text { I0 } \\ \text { Anæmia } & \ldots & \ldots & \ldots & \ldots & \ldots & \ldots & 4 \\ \text { Habit spasm } & \ldots & \ldots & \ldots & \ldots & \ldots & \ldots & 5 \\ \end{array}$

Of the above cases 3 had been previously diagnosed as acute rheumatism and I as chorea

The number of orthopædic cases is high and constitutes I2\% of the total number of patients with normal hearts. The various orthopædic lesions observed were :-

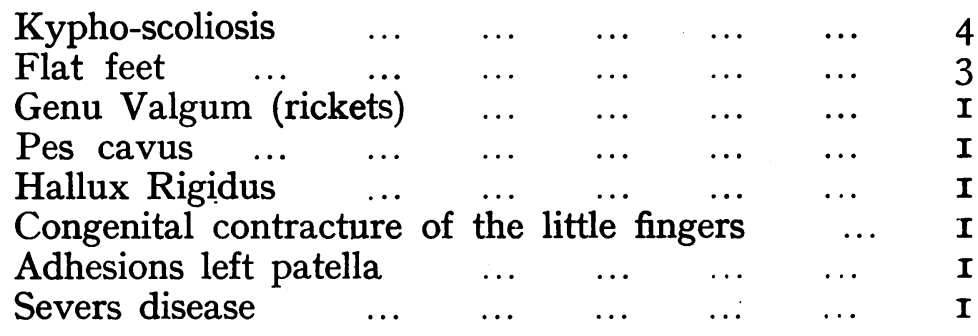


Group 2.-Cases in which the heart, although regarded as abnormal at some time during supervision, was regarded as normal by October 1934 .

The number of these cases was 43 , of which 14 had undergone treatment for the following conditions :-

Dental caries

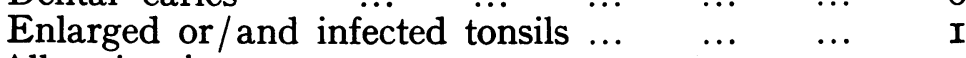

$\begin{array}{llllllll}\text { Albuminuria } & \ldots & \ldots & \ldots & \ldots & \ldots & \ldots & 3\end{array}$

$\begin{array}{lllllll}\text { Defective vision } & \ldots & \ldots & \ldots & \ldots & \ldots & \text { I }\end{array}$

$\begin{array}{llllllll}\text { Appendicitis } & \ldots & \ldots & \ldots & \ldots & \ldots & \ldots & \text { I }\end{array}$

$\begin{array}{llllllll}\text { Orthopædic } & \ldots & \ldots & \ldots & \ldots & \ldots & \ldots & 2\end{array}$

Orthopadic Cases.

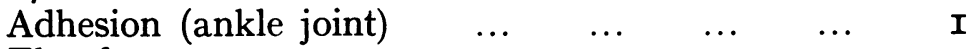

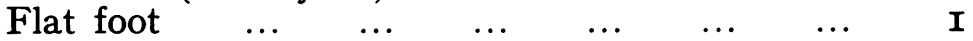

Some of the patients had more than one defect.

\section{Group 3.-Cases with Carditis.}

(Those who were still regarded as having abnormal hearts by October 1934).

These cases were I04 in all. II were attending schools for the physically defective. Of these latter one had aortic regurgitation and Io had mitral disease. The remainder (93) were attending elementary schools.

The following table is an analysis of the various cardiac lesions found in these I04 cases :-

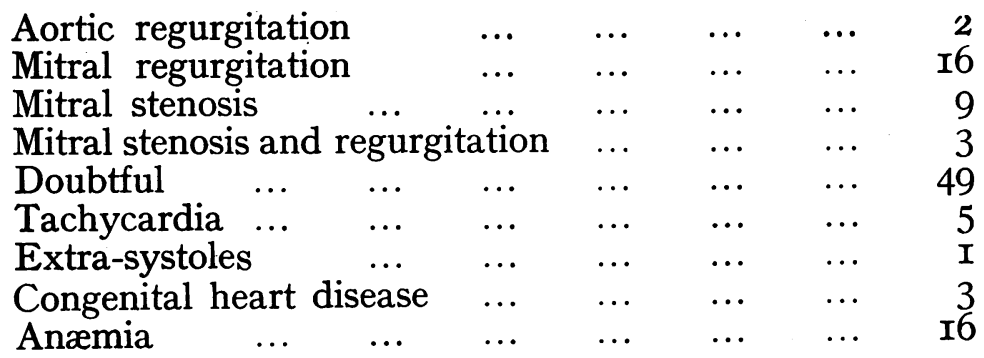

The doubtful cases were those in whom the first sound at the apex was not absolutely pure with or without some slight cardiac enlargement and in whom one felt there was a good chance of a disappearance of all evidence of cardiac disease.

The following other conditions were found in $4 \mathrm{I}$ of the above cases:-

Dental caries

тุ2

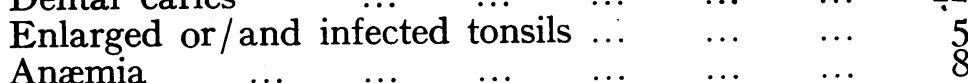

$\begin{array}{lllllll}\text { Albuminuria } & \ldots & \ldots & \ldots & \ldots & \ldots & 4\end{array}$

$\begin{array}{llllllll}\text { Bronchitis } & \ldots & \ldots & \ldots & \ldots & \ldots & \ldots & \text { I }\end{array}$

$\begin{array}{llllllll}\text { Appendicitis } & \ldots & \ldots & \ldots & \ldots & \ldots & \ldots & \text { I }\end{array}$

$\begin{array}{llllllll}\text { Hysteria } & \ldots & \ldots & \ldots & \ldots & \ldots & \ldots & \text { I }\end{array}$

$\begin{array}{llllllll}\text { Chilblains } & \ldots & \ldots & \ldots & \ldots & \ldots & \ldots & \text { I }\end{array}$

$\begin{array}{llllllll}\text { Leucorrhœa } & \ldots & \ldots & \ldots & \ldots & \ldots & \ldots & \text { I }\end{array}$

$\begin{array}{lllllll}\text { Graves' Disease } & \ldots & \ldots & \ldots & \ldots & \ldots & \text { I }\end{array}$

$\begin{array}{llllllll}\text { Orthopædic } & \ldots & \ldots & \ldots & \ldots & \ldots & \ldots & 6\end{array}$ 
The orthopædic cases are sub-divided as follows :-

$\begin{array}{lcccccc}\text { Tuberculous joint } & \ldots & \ldots & \ldots & \ldots & \ldots & \text { I } \\ \text { Flat feet } \ldots & \ldots & \ldots & \ldots & \ldots & \ldots & \text { 2 } \\ \text { Epiphysitis (ankle) } & \ldots & \ldots & \ldots & \ldots & \ldots & \text { I } \\ \text { Hallux rigidus } & \ldots & \ldots & \ldots & \ldots & \ldots & \text { I } \\ \text { Spondylitis } \ldots & \ldots & \ldots & \ldots & \ldots & \ldots & \text { I }\end{array}$

Therefore less than $6 \%$ of cases found to have cardiac changes had orthopædic conditions.

73 cases had enucleation of the tonsils performed before the onset of symptoms and 29 after (before attendance at the Clinic).

I4 cases had the operation at my suggestion.

The group of 49 doubtful cases is one in which it is impossible to prophesy results and such cases must necessarily be kept under observation.

\section{General Conclusions.}

Several conclusions can be drawn from the figures detailed above.

I. The high percentage of orthopædic defects found in cases with a normal heart is surprising. It suggests that many of the symptoms which are usually associated with the development of rheumatism or previously described as "growing pains " require much more careful investigation.

2. The very low proportion of cases of aortic regurgitation is remarkable. This suggests either that aortic regurgitation is becoming less common in children of school age, or that the condition when seen in the young is rapidly fatal, or that it develops after school life. I feel that the latter is probably the correct explanation, in which case the institution of clinics for young adults in post-school life becomes important. I should venture to suggest the possibility of the development of aortic regurgitation in several of those cases described as " Doubtful."

3. In all those cases $I$ have seen at the Stoke-Newington Clinic, I have yet to find a rheumatic nodule. I have looked very carefully in every case in those areas where it is usually described as occurring, i.e. the knees, elbows, occiput, backs of hands, spine, etc. The cases which I see at the Clinic are all ambulatory, which may be the explanation, since nodules are to be found mainly in the early stages of the particularly grave cases.

I am very much indebted to Miss Hugh, the assistant organiser, without whose help this report would have been impossible.

I have also to thank Sir Frederick Menzies for permission to publish this report. 